\title{
APLIKASI ANALISIS FAKTOR KONFIRMATORI TERHADAP SIKAP KEBERAGAMAAN MAHASISWA
}

\author{
Rijal Firdaos \\ IAIN Raden Intan Lampung \\ rijalfirdaos@radenintan.ac.id
}

\begin{abstract}
Abstrak
The aim of this research is to develop an instrument of religious attitude for Islamic students higher education at Tarbiyah Faculty of IAIN Raden Intan Lampung. The population of this research is Islamic students of Tarbiyah Faculty amounted to 150 people. The method research used survey technique. The Parameter of this research used Thurstone scale or called with equal appearing interval. The empirical research results through has confirmed 27 items are consist in three dimension. The result by using factor analysis of confirmatory is indicating that all items indicator have factor loading more than 0.30, and support which has estimated with enough theory. Construct reliabilities by Alpha Cronbach indicate that instruments developed have fulfilled limit acceptance of reliabilities coefficient more than 0.70 .
\end{abstract}

Keywords: Factor Analysis, Instrument Development, Religious Attitude.

\begin{abstract}
Abstrak
Penelitian ini bertujuan untuk mengembangkan instrumen sikap keberagamaan mahasiswa Fakultas Tarbiyah IAIN Raden Intan Lampung. Populasi dalam penelitian ini adalah mahasiswa Fakultas Tarbiyah berjumlah 150 orang. Metode dalam penelitian ini menggunakan teknik survey dengan menggunakan parameter Skala Thurstone atau biasa disebut dengan metode interval tampak setara. Hasil penelitian secara empiris menyatakan bahwa 27 item instrumen sikap keberagamaan mahasiswa tersebar ke dalam tiga dimensi. Hasil analisis faktor konfirmatori menunjukkan babwa semua item memiliki muatan faktor di atas 0.30, dengan asumsi babwa semua item yang diestimasikan sesuai dengan teori. Hasil uji reliabilitas instrumen dengan menggunakan alpha cronbach mengindikasikan bahwa instrumen yang dikembangakan tergolong tinggi dengan indeks berada di atas 0, 70 .
\end{abstract}

Kata Kunci: Analisis Faktor, Pengembangan Instrumen, Sikap Keberagamaan Permalink/DOI: http://dx.doi.org/10.18326/infsl3.v10i2.359-380 


\section{Pendahuluan}

Berjalannya masa hingga ihwal modernisasi dewasa ini, tidak terlepas dari sumbangan pendidikan dan ilmu pengetahuan sebagai metode sistematis yang terorganisir. Dalam perkembangannya, ilmu pengetahuan telah merangsang timbulnya gejala beragam bagi kemajuan dunia, yang secara baik telah membantu dalam setiap kebutuhan kelayakan hidup manusia. Laju moderinisasi yang seimbang dengan kompentensi sumber daya manusianya, mulanya didesain untuk menciptakan keramahan sikap, kebijakan berpikir, keadialan bertindak, serta tindak tanduk positif yang mendukung pada kesejahteraan kepentingan sesama. Begitupun sebaliknya, tingkat modernitas yang melaju cepat, seakan tak berdaya menahan laju tingginya kriminalitas.

Kasus kejahatan yang kini menyebar, tidak hanya berlaku bagi kaum awam. Sebagai masyarakat terpelajar, para mahasiswa pun, telah menjadi subjek dari tindakan kriminalitas tersebut. Baik itu tawuran antar kampus, kejahatan seksual, pembunuhan, bahkan termasuk menjadi teroris, yang dalam satu dekade terkahir menjadi bahan pembicaraan bagi seluruh negeri Indonesia. Bahkan, pembunuhan yang dilakukan oleh salah seorang mahasiswa terhadap dosen yang ada di salah satu Perguruan Tinggi di Sumatra Utara belum lama ini, menunjukkan bahwa kasus kejahatan telah menyebar pada masyarakat intelektual, yang notabene sebagai aset bangsa.

Terlebih lagi, sejak serangan yang terjadi pada tanggal 11 September di Amerika, dan tahun 2002 kasus bom Bali Satu, hampir seluruh sekolah-sekolah Islam yang ada di Asia Tenggara menjadi pusat perhatian dunia internasional. (Hefner, 2009: 1). Data di atas menujukkan, bahwa dewasa ini lembaga-lembaga pendidikan Islam yang sedianya memberikan pencerahan dan pembinaan bagi pemeluknya, ternyata belum mampu menjadi solusi bagi setiap problematika yang muncul, terlebih lagi hubungannya dengan paham kelompok tertentu, yang menganggap bahwa meledakkan bom atas dasar agama merupakan bagian daripada jihad.

Dalam iklim masyarakat yang kini mengalamai krisis identitas, pendidikan sikap religius dalam pandangan Mangunwijaya (1991: 
5) jauh lebih penting daripada pendidikan agama. Kecenderungan religius mendorong manusia melakukan berbagai upaya, sekalipun dengan mengorbankan perasaan individualistis dan naluriahnya. Menurut Mutahhari (2008: 21) hal ini dapat terjadi hanya bila idealnya sudah mencapai tingkat kesucian dan sepenuhnya mengendalikan eksistensinya.

Tak bisa dipungkiri, agama dalam kehidupan individu berfungsi sebagai suatu sistem nilai yang memuat norma-norma tertentu (Arifin, 2008: 143). Secara umum, norma-norma tersebut menjadi kerangka acuan dalam bersikap dan bertingkah laku agar sejalan dengan keyakinan agama yang dianutnya. Kajian psikologi agama telah menunjukkan bahwa timbulnya kesadaran beragama (religious consciousness) disebabkan adanya faktor baik dalam diri seseorang maupun dari faktor luar. Ramayulis (2011: 101), menjelaskan bahwa faktor dalam diri seseorang misalnya motif, kesediaan, dan harapan, sedangkan faktor luar berasal dari suatu obyek luar yang memengaruhi. Kemudian dalam mekanismenya, kesadaran beragama akan menimbulkan pengalaman beragama (religious experience), dan demikian seterusnya terkait secara timbal balik. Kesadaran dan pengalaman beragama ini sangat erat kaitannya dengan tingkah laku keagamaan.

Dalam perkembangannya, fenomena religius menurut Durkheim dalam Syukri (2011: 66), setidaknya dapat dibagi menjadi dua kategori: kepercayaan dan ritus. Yang pertama merupakan pendapat-pendapat (states of opinion) dan terdiri dari represnetasi-representasi; yang kedua adalah bentuk-bentuk tindakan (action) yang khusus. Di antara dua kategori fonomena ini terdapat jurang yang memisahkan cara berpikir (thinking) dari cara berperilaku (doing).

Ritus dapat dibedakan dari tindakan-tindakan (practice) manusia lainnya-misalnya tindakan moral (moral practice) berdasarkan kekhasan hakikat apa yang jadi objeknya. Seperti sebuah ritus, sebuah aturan moral menentukan cara kita bertingkah laku, tapi cara-cara bertingkah laku ini mengekspresikan jenis objek yang berbeda dari objek ritus.

Ritus adalah alat manusia religius untuk melakukan perubahan. Ia juga bisa dikatakan sebagai tindakan simbolis agama, 
atau ritual itu merupakan "agama dalam tindakan". Meskipun iman mungkin merupakan bagian dari ritual atau bahkan ritual itu sendiri, iman keagamaan berusaha menjelaskan makna dari ritual serta memberikan tafsiran dan mengarahkan vitalitas dari pelaksanaan ritual tersebut (Ghazali, 2011: 50). Kepercayaan religius selalu dianut oleh kelompok yang jelas menyatakan dan mempraktikan ritus-ritus yang sesuai dengan kepercayaan tersebut. Kepercayaan ini tidak hanya diterima secara individual oleh semua anggota kelompok, tapi juga menjadi milik dan dialah yang menyatukannya.

Manusia, dalam perspektif Nasr (2004: 3) dari satu titik pandang yang pasti adalah makhluk rasional, sebagaimana didefinisikan para pilosof, tetapi kemampuan rasional yang sekaligus perluasan dan refleksi intelek ini dapat menjadi kekuatan dan instrumen setan, jika dipisahkan dari intelek dan wahyu, yang dengan sendirinya memberikan kualitas dan kandungan sucinya. Oleh karena itu, lebih daripada sebagai "binatang rasional", seseorang dapat mendefinisikan manusia dalam suatu cara yang lebih substansial, sebagai makhluk yang diberkahi dengan suatu intelegensi penuh, berpusat pada Yang Absolut dan diciptakan untuk mengetahui Yang Absolut.

Alhasil, untuk memfasilitasi beberapa syarat di atas, perlu adanya instrumen terstandar dan baku, untuk mengukur tingkat keberagamaan mahasiswa, serta sikap-sikapnya, yang meliputi; keyakinan beragama, pengetahuan beragama, dan praktik keagamaan. Karena, menurut Bahtiar (2007: 256) kebutuhan manusia modern tidak saja sains dan teknologi. Tetapi kebutuhan rohani, termasuk kebutuhan akan masa depan, baik di dunia maupun sesudahnya.

\section{Kajian Teori}

Analisis faktor merupakan model yang pertama kali dikembangkan sebagai suatu metode untuk mengkaji sesuatu yang tidak dapat diamati. Seperti intelegensi, motivasi, kemampuan, sikap, dan opini. (Raykov, 2006: 116). Analisis faktor dibagi menjadi dua macam yaitu analisis komponen utama (principal component analysis $=$ PCA) dan 
analisis factor (factor analysis $=\mathrm{FA}$ ). Kedua analisis ini bertujuan menerangkan struktur ragam-ragam melalui kombinasi linier dari variabel-variabel pembentuknya. Sehingga dapat dikatakan bahwa factor atau komponenadalah variabel bentukan bukan variabel asli.

Menurut Kerlinger (2004: 1000), analisis faktor berfungsi melayani tujuan keiritan upaya ilmiah. Ia mengurangi kelipatgandaan tes dan pengukuran hingga menjadi jauh lebih sederhana. Walhasil, analisis faktor memberitahu kita tes-tes dan ukuran-ukuran yang saling dapat serasi atau sama tujuannya, dan sejauh manakah kesamaan itu. Tujuan utama analisis faktor adalah untuk menjelaskan struktur hubungan di antara banyak variabel dalam bentuk faktor atau variabel laten atau variabel bentukan. Faktor yang terbentuk merupakan besaran acak (random quantities) yang sebelumnya tidak dapat diamati atau diukur atau ditentukan secara langsung.

Sementara instrumen merupakan alat bantu yang digunakan oleh peneliti untuk mengumpulkan data dengan cara melakukan pengukuran. Cara ini dilakukan untuk memperoleh data yang objektif yang diperlukan untuk menghasilkan kesimpulan penelitian yang objektif pula. (Purwanto, 2010: 183). Menurut Colton dan Covert, Instrument is a mechanism for measuring phenomena, which is used to gather and record information for assessment, decision making, and ultimately understanding (Colton dan Covert, 2007: 5) Instrumen sepertihalnya kuesioner merupakan salah satu bagian yang digunakan untuk memperoleh informasi yang faktual, mengobservasi, atau menilai suatu sikap dan opini.

Respon yang diperlukan untuk pengukuran atribut kognitif, tidak sama dengan respon yang diperlukan untuk pengukuran atribut non kognitif. Untuk pengukuran atribut kognitif diperlukan respon jenis pendapat (judgment) yaitu jenis respon yang dapat benar atau salah. Untuk pengukuran atribut non kognitif, menurut Suryabrata (2005: 177) diperlukan respon jenis ekpresi sentiment (expression of sentiment), yaitu jenis respon yang tak dapat dinyatakan benar atau salah, atau sering kali dikatakan semua respon benar menurut alasan masing-masing. Dalam konteks penelitian ini, variabel sikap keberagamaan merupakan variabel laten yang tidak dapat diamati secara langsung, melainkan dengan pendekatan pengujian 
secara pendekatan konstruk. Meski demikian, konstruk memiliki keterkaitan teori antara satu dengan lainnya. (Harrington, 2009: 5).

Untuk lebih spesifik, Djaali dkk (2005: 177), langkah-langkah pengembangan instrumen adalah sebagai berikut: (1) konstruk dirumuskan berdasarkan sintesis dari teori-teori yang dikaji, (2) dikembangkan dimensi dan indikator berdasarkan konstruk, (3) dibuat kisi-kisi instrumen dalam bentuk tabel spesifikasi yang memuat dimensi, indiator, nomor butir dan jumlah butir, (4) ditetapkan besaran atau parameter yang bergerak dalam suatu rentangan kontinum, (5) butir-butir instrument ditulis dalam bentuk pernyataan atau pertanyaan, (6) proses validasi, (7) proses validasi pertama adalah validasi teoritik melalui panel, (8) revisi berdasarkan hasil panel, (9) instrument digandakan secara terbatas guna ujicoba, (10) ujicoba merupakan validasi empiric, (11) pengujian validitas dengan menggunakan criteria internal maupun eksternal, (12) beredasarkan criteria diperoleh kesimpulan mengenai valid atau tidaknya sebuah butir atau perangkat instrument, (13) validitas internal berdasarkan hasil analisis butir, (14) dihitung koefisien reliabilitas, dan (15) perakitan butir-butir instrument yang valid untuk dijadikan instrumen.

Selanjutnya, terkait dengan instrumen yang akan dikembangkan, Mastuhu (2006: 1) menjelaskan, bahwa pengalaman beragama (religious experience), yaitu penghayatan kepada Tuhan, manusia menjadi memiliki kesanggupan, kemampuan dan kepekaan rasa untuk menegenal dan memahamai esksitensi sang Ilahi. Secara sosilogis, agama merupakan kategori sosila dan tindak empiris. Hadi dalm Kasmahidayat (2010: 27), mendefinisikan sikap keberagamaan (religiousity) sebagai ikatan antara seseorang atau manusia dengan yang Maha Tinggi, Yang Abadi, Yang Tunggal, dan Yang Tanzih (Transenden). Jika kata sikap keberagamaan dikenakan pada seni, dapat diartikan sebagai karya-karya yang mengungkapkan atau menghadirkan suasana adanya ikatan atau keterikatan jiwa manusia, bahkan ketergantungan atau penyerahan kepada Yang Maha Tinggi, yakni Yang Maha Kuasa. Makna religiositas dalam konteks ini adalah suatu bangun ikatan antara hamba dengan Tuhannya, serta penyerahan diri seseorang atas hidup dan kehidupannya hanya kepada Dzat yang Mahatinggi dan Mahakuasa. 
Sutrisno (2005: 183), menerangkan sikap keberagamaan sebagai keruhanian atau spiritualitas, dalam arti kesadaran manusia bahwa nilai, arah, dan orientasi hidupnya ditentukan oleh hubungannya yang damai dengan Ilahi, Yang Suci. Sikap keberagamaan juga diartikan sebagai potensi atau kemampuan yang pokok dari kebudayaan manusia dalam menghayati hidupnya berdasarkan pada nurani yang dekat dengan Sang Sumber Cahaya, yaitu Tuhan.

Sementara pendapat yang berbeda dikemukakan Sutrisno di atas, bahwa religiositas diwujudkan pada spiritual. Dengan kata lain, bahwa manusia dengan bekal potensi keruhaniaan dalam dirinya, mampu menjadi media komunikasi antara hamba dengan Tuhannya, serta dapat pula dijadikan sebagai sandaran hidup seseorang, dalam menghayati dan menjalankan kehidupan di dunia. Mulai dari kehidupan, rizki, dan kematian.

Agama lebih-lebih teologi-tidak lagi terbatas hanya sekedar menerangkan hubugan antara manusia dan Tuhan-Nya, tetapi secara tidak terelakkan juga melibatkan kesadaran berkelompok (sosiologis), kesadaran pencarian asal usul agama (antropologis), pemenuhan kebutuhan untuk membentuk kepribadian yang kuat dan ketenangan jiwa (psikologis) bahkan ajaran agama tertentu dapat diteliti sejauh mana keterkaitan ajaran etikanya dengan corak pandangan hidup yang memberi dorongan kuat untuk memperoleh derajat kesejahteraan hidup yang optimal (ekonomi).

Perkembangan teknologi dan ilmu pengetahuan, termasuk di dalamnya perkembangan ilmu-ilmu sosial kemanusiaan, yang begitu pesat secara relatif memperdekat jarak perbedaan budaya antara suatu wilayah dan wilayah lainnya. Hal demikian dalam pandangan Amin Abdullah (2004: 9), pada gilirannya juga mempunyai pengaruh yang cukup besar terhadap kesadaran beragama manusia tentang apa yang disebut fenomena "agama". Agama untuk era sekarang tidak dapat lagi didekati dan difahami hanya lewat pendekatan teologis-normatif semata-mata.

Dalam bahasa agama, bahwa seseorang yang memiliki keimanan dan tingkat ketakwaan yang baik, maka secara praktis akan memerhatikan kualitas kesalehan sosialnya melalui berbagi terhadap sesamanya. Sementara pada hal lain, orang bertakwa juga 
senantiasa mampu mengelola emosinya, serta ia memiliki sikap pemaaf bagi sesamanya. Dalam hal ini jelaslah, bahwa perilaku keberagamaan seseorang yang diwarnai dengan beragam ranah (kognitif, afektif, dan afeksi) akan mencerminkan pribadi yang unggul. Di samping itu bahwa karakteristik orang yang bertakwa adalah mereka yang apabila lalai setelah melakukan perbuatan yang tidak baik, atau setelah mereka mendzalimi diri mereka sendiri, mereka akang segera bertaubat, dan memohon ampun kepada Allah, serta tidak akan mengulangi perbuatan keji tersebut.

Pernyataan di atas memberikan pengertian kepada kita bahwa setiap pribadi tentu memilki pengalaman beragama yang berbeda, sesuai dengan kemampuan individu mereka masingmasing terhadap bagaimana memahami dan melaksanakan prinsip agama yang diyakini selama ini. Namun, idealnya, pengalaman beragama seseorang, menurut Carr dan Haldane (2003: 156), akan mampu menembus nilai penghayatan akan eksistensi Tuhan sebagai kekuatan yang tinggi.

Warwanto (2009: 17), mengatakan, Pendidikan sikap keberagamaan adalah komunikasi iman antara siswa yang seagama maupun berlainan agama mengenai pengalaman hidup mereka yang digali maknanya, sehingga mereka terbantu untuk menjadi manusia utuh (religius, bermoral, terbuka). Dengan cara ini diharapkan mereka mampu jadi pelaku perubahan sosial, demi terwujudnya kesejahteraan bersama lahir dan batin.

Sementara di sisi lain, Warwanto mengemukakan bahwa religiositas sebagai komunikasi iman antara siswa beragama maupun berbeda agama, dengan tujuan untuk menjadi insan yang religius, bermoral, dan terbuka. Religius artinya, bahwa seseorang sedianya akan bersikap dan berperilaku sesuai dengan aturan main yang berlaku dari prinsip agamanya.

Sebab, dalam pandangan Mangunwijaya (1991: 6), pada tingkat sikap keberagamaan, bukan peraturan atau hukum yang berbicara, akan tetapi keihklasan, kesukaran, kepasrahan diri kepada tuhan. Dalam rasa hormat takjub, namun juga dalam rasa cinta. Dalam suasana pujaan yang tidak lagi mencari menang, karena tergenang oleh rasa syukur penuh rendah diri. 
Adapun tujuan utama dalam penelitian ini adalah di samping untuk mengembangkan instrumen baku yang memenuhi persyaratan dalam mengukur sikap keberagamaan Mahasiswa Fakultas Tarbiyah IAIN Raden Intan Lampung, juga untuk mengetahui dimensi apa saja yang mendasari instrumen sikap keberagamaan mahasiswa, untuk mengetahui bagaimanakah validitas konstruk instrumen sikap keberagamaan Mahasiswa, serta untuk mengetahui bagaimanakah reliabilitas instrumen sikap keberagamaan Mahasiswa Fakultas Tarbiyah Raden Intan.

\section{Metode}

Penelitian ini merupakan penelitian pengembangan, yang bertujuan untuk mengembangkan dan memvalidasi instrumen sikap keberagamaan mahasiswa Fakultas Tarbiyah IAIN Raden Intan Lampung. Terkait dengan tujuan di atas, rancangan penelitian ini menggunakan teknik pengembangan produck (Richey dan Klien, 2007: 9). Siklus research and development menurut Semiawan (2008: 181) mencakup penemuan penelitian terhadap produk yang akan dihasilkan, mengkajinya kembali dalam setting di mana hasilnya tersebut digunakan dan merevisinya sampai kajian tersebut dianggap memadai.

Populasi dalam penelitian ini adalah seluruh mahasiswa Fakultas Tarbiyah IAIN Raden Intan yang terdiri dari 10 Jurusan. Adapun teknik pengambilan sampel dalam penelitian ini menggunakan sampling kuota. Yaitu, menentukan sampel dari populasi yang mempunyai ciri-ciri tertentu sampai jumlah (kuota) yang diinginkan.

Parameter hasil ukur dalam penelitian ini menggunakan Skala Thurstone atau sering juga disebut dengan equal appearing interval. Metode ini merupakan salah satu model penskalaan pernyataan sikap dengan menggunakan stimulus (Azwar, 2011: 126). Penskalaan dalam pendekatan ini ditujukan untuk meletakkan stimulus atau pernyataan sikap pada suatu kontinum psikologis yang akan menunjukkan derajat favorable atau tak favorablenya pernyataan yang bersangkutan. 


\section{Hasil Analisis Faktor dan Pengujian Reliabilitas}

Pada pelaksanaan uji coba dalam penelitian ini, kuesioner yang digunakan sebanyak 30 butir pernyataan kuesioner sikap keberagamaan yang diujicobakan kepada 150 mahasiswa Fakultas Tarbiyah dan Keguruan IAIN Raden Intan Lampung.

Tahap pertama pada analisis faktor adalah menilai mana saja variabel yang dianggap layak untuk dimasukkan dalam analisis selanjutnya. Pengujian ini dilakukan dengan memasukkan semua variabel yang akan diujikan. Logika pengujian adalah jika sebuah variabel memang mempunyai kecenderungan mengelompok dan membentuk sebuah faktor, maka variabel tersebut akan mempunyai korelasi yang cukup tinggi dengan variabel lain. Di bawah ini adalah perhitungan hasil SPSS masing-masing dimensi.

\section{Dimensi Keyakinan}

Hasil perhitungan analisis faktor dimensi Keyakinan diperoleh KMO sebesar: 0, 693 tergolong sedang, dengan nilai chi-square= 166.456 dengan signifikansi ( $\mathrm{Sig}=0,000$ pada $\mathrm{dk}$ : 36) menunjukkan nilai dengan taraf signifikansi yang berada di bawah 0,05 . Ini berarti matriks korelasi yang terbentuk bukan matriks identitas sehingga semua variabel butir dimensi keyakinan yang dianalisis layak untuk dilakukan analisis lanjutan.

\section{Tabel 1}

\section{Hasil Uji Kelayakan Pensampelan KMO dan Uji Bartlett Dimensi Keyakinan}

\begin{tabular}{cccc}
\hline \multirow{2}{*}{ KMO MSA } & \multicolumn{3}{c}{ Bartlett's Test of Sphericity } \\
\hline 0.693 & 166.456 & 36 & 0.000 \\
\hline $\begin{array}{c}\text { Pemeriksaan angka } \\
\text { MSA }\end{array}$ & menunjukkan bahwa dari 9 \\
butir instrumen dimensi keyakinan semua butir yang dianalisis \\
menunjukkan nilai yang lebih besar $(>0,5)$, yaitu; A1: 0,519, A2:
\end{tabular}


0,684, A3: 0,722, A4, 0,694, A5: 0,703, A6: 0,686, A7: 0,546, A8: 0,725, A9: 0,738. Adapun kriteria signifikasinya adalah: Angka Sig. > 0,05 maka Ho diterima. Angka Sig. $<0,05$ maka Ho ditolak. Angka MSA (Measeure of Sampling Adequacy) berkisar 0 sampai 1 dengan kriteria: (a) MSA=1, variabel tersebut dapat diprediksi tanpa kesalahan oleh variabel lain. MSA $>0,05$, variabel masih bisa diprediksi dan bisa dianalisis lebih lanjut. MSA $<0,5$, variabel tidak bisa diprediksi dan tidak bisa dianalisis lebih lanjut, atau dikeluarkan dari variabel lainnya (Santoso, 2014; 66). Hasil rekapitulasi nilai MSA yang keseluruhannya memiliki nilai di atas, 0,05, dengan asusmsi bahwa semua variabel layak untuk dilakukan analisis lanjutan.

Selanjutnya dilakukan proses inti analisis faktor, yakni melakukan ekstraksi terhadap sekumpulan variabel yang ada, sehingga terbentuk satu atau lebih faktor. Metode pembuatan faktor (ekstrasi faktor) digunakan metode Principal Component dan ditampilkan pada tabel Communalities sebagai hasil ekstrasi. Pada butir (A1) yaitu: 0.707 atau $70 \%$ varians dari variabel butir 7 bisa dijelaskan oleh faktor yang terbentuk, (A2) 0.660 atau 66\% varians dari variabel yang terbentuk, (A3) 0.583 atau 58\%, (A4) 0.708 atau 70\%, (A5) 0.69 atau 69\%, (A7) 0.663 atau 63\%, (A8) 0.554 atau 54\%, dan (A9) 0.636 atau 63\%. Prosentase varians terkecil adalah 0,554 pada butir 8 , atau 55, \% varians dari variabel butir 8 bisa dijelaskan oleh faktor yang terbentuk.

Analisis keseluruhan varians yang dapat dijelaskan oleh komponen yang terbentuk dengan nilai eigenvalues lebih besar dari 1.00 dimana terdapat (empat) faktor dengan jumlah eigenvalues lebih besar (>) dari 1.00. dan 1 (satu) faktor memiliki nilai eigenvalues terbesar, yaitu faktor 2 (2.441), yang kemudian diikuti dengan faktor 2 (1.2609), sehingga secara kumulatif ke 4 faktor tersebut adalah sebesar 65.540 variansi.

Hasil analisis keanggotaan faktor dengan menggunakan metode Principal Component Analysis dengan metode rotasi varimax with Kaiser Normalization, dapat disimpulkan, bahwa pada rotated component matrix dilakukan 5 (lima) putaran atau iterasi yang memperlihatkan distribusi variabel butir yang lebih jelas dan nyata. Hasil rotasi menunjukkan bahwa ada 4 (empat) 
faktor diuji konstruknya dengan ketentuan kriteria pembatas yang nilai muatan (loading) lebih besar dari 0.30. Terbentuknya (empat) faktor yang telah dikonfirmasi konstruknya pada keseluruhan butir dimensi Keyakinan, memiliki 9 butir pernyataan yang memenuhi ketentuan muatan lebih besar 0.30.

Tabel 2.

Faktor dan Keanggotaan Faktor

\begin{tabular}{crcc}
\hline Faktor & Anggota & Muatan Faktor & Jumlah \\
\hline \multirow{2}{*}{1} & A5 & 0.790 & \\
& A9 & 0.740 & 3 \\
& A6 & 0.714 & \\
2 & A2 & 0.790 & 2 \\
& A8 & 0.560 & \\
\multirow{2}{*}{3} & A4 & 0.825 & 2 \\
& A3 & 0.557 & 2 \\
& A1 & 0.807 & \\
\hline
\end{tabular}

Tabel di atas menunjukkan bahwa 9 butir item yang dikonstruk pada dimensi keyakinan, setelah dilakukan analisis faktor terbentuk menjadi empat fakor, yang masing-masing faktor diberi nama sebagai berikut: Faktor pertama dengan jumlah 3 butir item diberi nama faktor keyakinan terhadap teologi tertentu, faktor kedua dengan jumlah 2 butir diberi nama faktor keyakinan terhadap Tuhan, faktor ketiga dengan jumlah 2 butir item diberi nama dengan faktor keyakinan terhadap Nabi, dan faktor keempat dengan 2 butir item diberi nama dengan faktor keyakinan terhadap sesuatu yang ghaib.

\section{Dimensi Pengetabuan}

Perhitungan analisis faktor dengan menggunakan bantuan program SPSS for windows versi 15 . Hasil perhitungan analisis faktor 
dimensi Mengelola Emosi diperoleh KMO sebesar: 0, 753 tergolong sedang, dengan nilai chi-square $=186,545$ dengan signifikansi (Sig= 0,000 pada dk: 36) menunjukkan nilai dengan taraf signifikansi yang berada di bawah 0,05. Dengan demikian, analisis faktor bisa dilanjutkan.

\section{Tabel 3.}

\section{Hasil Uji Kelayakan Pensampelan KMO dan Uji Bartlett Dimensi Pengetahuan Beragama}

\begin{tabular}{ccccc}
\hline \multirow{2}{*}{ KMO MSA } & \multicolumn{3}{c}{ Bartlett's Test of Sphericity } \\
& Approx. Chi-Square & df & Sig. \\
\hline 753 & 186.545 & 36 & 0.000 \\
\hline
\end{tabular}

Pemeriksaan angka MSA dari 9 butir instrumen dimensi pengetahuan semua butir yang dianalisis menunjukkan nilai yang lebih besar (> 0,5), yaitu; (A10) yaitu 0,519, (A11) yaitu 0,684, (A12) yaitu 0,722, (A13) yaitu 0,694, (A14) yaitu 0,703, (A15) yaitu 0,686, (A16) yaitu 0,546, (A17) yaitu 0, 725, dan (A18) yaitu 0, 738.

Setelah tahap pertama, yaitu melakukan penyaringan terhadap sejumlah variabel sehingga dipastikan bahwa semua variabel memenuhi sarat untuk dianalisis, selanjutnya dilakukan proses inti analisis faktor, yakni melakukan ekstraksi terhadap sekumpulan variabel yang ada, sehingga terbentuk satu atau lebih faktor.

Selanjutnya dilakukan proses inti analisis faktor, yakni melakukan ekstraksi terhadap sekumpulan variabel yang ada, sehingga terbentuk satu atau lebih faktor. Metode pembuatan faktor (ekstrasi faktor) digunakan metode Princip Component Analysis, dengan hasil sebagai berikut: Angka pada butir 10 (A10) yaitu 0.534 berarti sekitar 53\% varians dari variabel butir 10 dapat dijelaskan oleh factor yang terbentu. (A12) yaitu: 0,952 berarti sekitar 95\% varians dari variabel butir 12 bisa dijelaskan oleh faktor yang terbentuk. (A13) sebesar 0.424 atau 42\%, (A14) sebesar 0.597 atau 59\%, (A15) 0.463 atau 46\%, (A16) 0.700 atau 70\%, (A18) sebesar 0.952 atau 95\%, 
dengan nilai terbesar pada butir 12 yaitu 95\%, dan nilai terkecil pada butir 13 dengan presentasi sebesar 42\%. Dengan ketentuan semakin besar communalities sebuah variabel, berarti semakin erat hubungannnya dengan faktor yang terbentuk.

Hasil analisis keseluruhan varians yang dapat dijelaskan oleh komponen yang terbentuk dengan nilai eigenvalues lebih besar dari 1.00 dimana terdapat (empat) faktor dengan jumlah eigenvalues lebih besar ( >) dari 1.00. dan 1 (satu) faktor memiliki nilai eigenvalues terbesar, yaitu faktor 1 (3.143), yang kemudian diikuti dengan faktor 2 (2.381), sehingga secara kumulatif ke 2 faktor tersebut adalah sebesar 61.371 variansi.

Hasil analisis keanggotaan faktor dengan menggunakan metode Principal Component Analysis dengan metode rotasi varimax with Kaiser Normalization ditunjukkan pada table di bawah ini:

Tabel 4.

Faktor dan Keanggotaan Faktor

\begin{tabular}{cccc}
\hline Faktor & Anggota & Muatan Faktor & Jumlah \\
\hline \multirow{4}{*}{1} & A10 & 0.727 & \\
& A11 & 0.618 & \\
& A13 & 0.650 & 6 \\
& A14 & 0.747 & \\
& A15 & 0.677 & \\
2 & A17 & 0.673 & 3 \\
& A12 & 0.973 & \\
\hline
\end{tabular}

Tabel di atas menunjukkan bahwa 9 butir item yang dikonstruk pada dimensi pengetahuan, setelah dilakukan analisis faktor terbentuk menjadi dua fakor, yang masing-masing faktor diberi nama sebagai berikut: Faktor pertama dengan jumlah 6 butir item diberi nama faktor pengetahuan terhadap akidah, dan faktor 
kedua dengan jumlah 3 butir item diberi nama faktor pengetahuan terhadap simbol keagamaan.

\section{Dimensi Praktik Keagamaan}

Perhitungan analisis faktor dengan menggunakan bantuan program SPSS for windows versi 15. Hasil perhitungan analisis faktor motivasi diri diperoleh KMO sebesar: 0, 814 tergolong tinggi, dengan nilai chi-square $=474,946$ dengan signifikansi $(\mathrm{Sig}=0,000$ pada $\mathrm{dk}$ : 15$)$ menunjukkan nilai dengan taraf signifikansi yang berada di bawah 0,05. Artinya semua variabel butir dimensi motivasi diri yang dianalisis layak untuk dilakukan analisis lanjutan.

\section{Tabel 5.}

Hasil Uji Kelayakan Pensampelan KMO dan Uji Bartlett Dimensi Praktik Keagamaan

\begin{tabular}{rcrcc}
\hline \multirow{2}{*}{ KMO MSA } & \multicolumn{4}{c}{ Bartlett's Test of Sphericity } \\
& Approx. Chi-Square & df & Sig. \\
\hline 0.647 & 156.771 & 36 & 0.000 \\
\hline
\end{tabular}

Selanjutnya pemeriksaan angka MSA ditunjukan pada tabel di bawah ini dari 6 butir instrumen dimensi Praktik Keagamaan semua butir yang dianalisis menunjukkan nilai yang lebih besar $(>0,5)$.

Setelah tahap pertama, yaitu melakukan penyaringan terhadap sejumlah variabel sehingga dipastikan bahwa semua variabel memenuhi sarat untuk dianalisis, selanjutnya dilakukan proses inti analisis faktor, yakni melakukan ekstraksi terhadap sekumpulan variabel yang ada, sehingga terbentuk satu atau lebih faktor.

Pemeriksaan angka MSA dari 9 butir instrumen dimensi praktik keagamaan semua butir yang dianalisis menunjukkan nilai yang lebih besar (> 0.5), yaitu; (A19) yaitu 0.520, (A20) yaitu 0.621, 
(A21) yaitu 0,719, (A22) yaitu 0.694, (A33) yaitu 0.701, (A24) yaitu 0.686, (A25) yaitu 0.540, (A26) yaitu 0, 755, dan (A27) yaitu 0. 729.

Metode pembuatan faktor (ekstrasi faktor) digunakan metode Principal Component Analysis dan ditampilkan pada tabel Communalities sebagai hasil ekstrasi. Selanjutnya dilakukan proses inti analisis faktor, yakni melakukan ekstraksi terhadap sekumpulan variabel yang ada, sehingga terbentuk satu atau lebih faktor. Metode pembuatan faktor (ekstrasi faktor) digunakan metode Princip Component Analysis, dengan hasil sebagai berikut: Angka pada butir 19 (A19) yaitu 0.677 berarti sekitar 67\% varians dari variabel butir 19 dapat dijelaskan oleh faktor yang terbentuk. (A20) yaitu: 0.503 berarti sekitar 50\% varians dari variabel butir 20 bisa dijelaskan oleh faktor yang terbentuk. (A21) sebesar 0.465 atau 46\%, (A22) sebesar 0.398 atau 39\%, (A23) 0.421 atau 42\%, (A24) 0.667 atau 67\%, (A25) sebesar 0.683 atau $68 \%$, dengan nilai terbesar terdapat pada butir 25 yaitu 68\%, dan nilai terkecil pada butir 22 dengan presentasi sebesar 39\%. Dengan ketentuan semakin besar communalities sebuah variabel, berarti semakin erat hubungannnya dengan faktor yang terbentuk.

Hasil analisis keseluruhan varians yang dapat dijelaskan oleh komponen yang terbentuk dengan nilai eigenvalues lebih besar dari 1.00 dimana hanya terdapat (satu) faktor saja dengan jumlah eigenvalues lebih besar (>) dari 1.00. dan 1 (satu) faktor memiliki nilai eigenvalues terbesar, (2.317) yang kemudian diikuti dengan faktor 2 (1.376), sehingga secara kumulatif ke 4 faktor tersebut adalah sebesar 53.965 variansi.

Hasil analisis keanggotaan faktor dengan menggunakan metode Principal Component Analysis dengan metode rotasi varimax with Kaiser Normalization.

Dari tabel di atas dapat disimpulkan, bahwa pada rotated component matrix dilakukan (empat) putaran atau iterasi yang memperlihatkan distribusi variabel butir yang lebih jelas dan nyata. Hasil rotasi menunjukkan bahwa ada 3 (tiga) faktor diuji konstruknya dengan ketentuan kriteria pembatas yang nilai muatan (loading) lebih besar dari 0.30. Terbentuknya (tiga) faktor yang telah dikonfirmasi konstruknya pada keseluruhan butir dimensi 
pengalaman beragama, memiliki 9 butir pernyataan yang memenuhi ketentuan muatan lebih besar 0.3.

Tabel 6.

Faktor dan Keanggotaan Faktor

\begin{tabular}{cccc}
\hline Faktor & Anggota & Muatan Faktor & Jumlah \\
\hline \multirow{4}{*}{1} & & & \\
& A20 & 0.557 & \\
& A21 & 0.677 & 4 \\
& A26 & 0.702 & \\
A27 & 0.626 & \\
& & & \\
2 & A22 & 0.620 & 3 \\
& A23 & 0.446 & \\
& A24 & 0.812 & \\
& & & \\
& A19 & 0.785 & 2 \\
\hline
\end{tabular}

Tabel di atas menunjukkan bahwa 9 butir item yang dikonstruk pada dimensi praktik, setelah dilakukan analisis faktor terbentuk menjadi tiga fakor, yang masing-masing faktor diberi nama sebagai berikut: Faktor pertama dengan jumlah 4 butir item diberi nama praktik terhadap kewajiban ritual, faktor kedua dengan jumlah 3 butir item diberi nama mentaati perintah agama, dan faktor ketiga dengan jumlah dua butir item diberinama dengan komitmen terhadap agama yang diyakini. Untuk lebih jelas di bawah ini adalah rekapitulasi penamaan faktor dan jumlah butir item untuk ketiga dimensi sikap keberagamaan. 


\section{Tabel 7.}

Rekapitulasi Dimensi dan Penamaan Faktor

\begin{tabular}{|c|c|c|c|}
\hline No & Dimensi & Penamaan Faktor & Jumlah Butir \\
\hline \multirow{4}{*}{1} & \multirow{4}{*}{ Keyakinan } & $\begin{array}{l}\text { Keyakinan terhadap teologi } \\
\text { tertentu }\end{array}$ & 3 butir \\
\hline & & Keyakinan terhadap Tuhan & 2 butir \\
\hline & & Keyakinan terhadap Nabi & 2 butir \\
\hline & & Keyakinan terhadap hal gaib & 2 butir \\
\hline \multirow{2}{*}{2} & \multirow{2}{*}{ Pengetahuan } & $\begin{array}{l}\text { Pengetahuan } \quad \text { terhadap } \\
\text { akidah }\end{array}$ & 6 butir \\
\hline & & $\begin{array}{ll}\text { Pengetahuan } & \text { terhadap } \\
\text { simbol keagaaan } & \end{array}$ & 3 butir \\
\hline \multirow{3}{*}{3} & \multirow{3}{*}{ Praktik } & Melakukan kewajiban ritual & 4 butir \\
\hline & & $\begin{array}{l}\text { Kewajiban mentaati perintah } \\
\text { agama }\end{array}$ & 3 butir \\
\hline & & $\begin{array}{l}\text { Komitmen terhadap agama } \\
\text { yang diyakini }\end{array}$ & 2 butir \\
\hline & Jumlah & & 27 butir \\
\hline
\end{tabular}

Pada langkah analisis faktor selanjutnya, pendekatan konfirmatori dilakukan melaluii komputasi dengan metode kebolehjadian maksimum atau maximum likelihood untuk menguji apakah data pada estimasi model hubungan yang telah disusun berdistribusi normal multivariate. Komputasi dengan metode maximum likelihood, pada goodness of fit test diperoleh hasil sebagai berikut: 
Tabel 8.

\section{Hasil Goodness of Fit Test}

\begin{tabular}{|c|c|c|}
\hline \multicolumn{3}{|c|}{ Goodness-of-fit Test } \\
\hline Chi-Square & df & Sig. \\
\hline 408.272 & 18 & .000 \\
\hline
\end{tabular}

Berdasarkan hasil di atas, menujukkan bahwa komputasi dengan menggunakan metode Maximum Likelihood, pada goodness of fit test menghasilkan indeks sebesar 408,272 dengan derajat kebebasan 18 dan p value 000 sehingga dapat disimpulkan data berdistribusi normal multivariat. Hal ini berarti instrumen sikap keberagamaan mahasiswa yang telah disusun dan dikembangkan memiliki validitas konstruk yang baik.

\section{Reliabilitas Instrumen}

Selanjutnya menghitung indeks relibilitas instrumen. tujuan dilakukannya indeks ini adalah untuk mengetahui seberapa tinggi instrumen teresebut memiliki nilia reliabilitasnya. Sebab, dalam kenyatannya, bahwa setiap alat ukur hendaknya memiliki nilai reliabilitas yang berada $>0,70$. Adapun untuk koefisien reliabilitas dalam penelitian ini digunakan koefisien Cronbach's Alpha dan diperoleh sebagai berikut:

Tabel 9.

Koefisien Reliabilitas

\begin{tabular}{|c|c|c|}
\hline $\begin{array}{c}\text { Cronbach's } \\
\text { Alpha }\end{array}$ & $\begin{array}{l}\text { Cronbach's } \\
\text { Alpha } \\
\text { Based on } \\
\text { Standardized } \\
\text { Items }\end{array}$ & $\begin{array}{l}\mathrm{N} \text { of } \\
\text { Items }\end{array}$ \\
\hline .852 & .871 & 27 \\
\hline
\end{tabular}


Data di atas menunjukkan bahwa nilai koefisiean reliabilitas Alpha sebesar $(0,82)$ sehingga dapat dikatakan bahwa butir-butir instrumen sikap keberagamaan tersebut memiliki konsistensi internal yang tinggi.

\section{Penutup}

Berdasarkan hasil penelitian tentang studi analisis faktor teradap sikap keberagamaan mahasiswa, dapat disimpulkan sebagai berikut: Pertama, ekstrasi dan rotasi faktor dengan menggunakan metode konfirmatori pada tahap empiris telah mengkonfirmasi 9 (sembilan) faktor. dengan muatan faktor terbesar 0.965 pada dimensi konsekuensi, dan muatan faktor terkecil 0. 596 pada dimensi keyakinan, dengan jumlah varians faktor yang terbentuk pada masing-masing dimensi.

Kedua, hasil uji kelayakan sampel KMO (Keiser-MeiyerOlkin) pada ke 3 dimensi dengan angka KMO 0,693 untuk dimensi keyakinan, dimensi pengetahuan sebesar 0.753 dan dimensi praktik sebesar 0. 647. Demikian pula untuk uji Bartlett menunjukkan bahwa matriks yang terbentuk pada uji kelayakan bukan matriks identitas dengan chi-kuadrat dimensi keyakinan sebesar 166.456 dengan $\mathrm{df}=$ 36, dimensi pengetahuan sebesar 186.545 dengan $\mathrm{df}=36$, dimensi praktik sebesar 156.771 dengan $\mathrm{df}=36$. Selanjutnya pemeriksaan terhadap nilai MSA (measure of sampling adequacy) pada tabel anti image correlation dilakukan untuk mengidentifikasi bahwa pensampelan telah cukup memenuhi syarat untuk dilanjutkannya analisis faktor dengan ketentuan nilai MSA $>0.5$, dengan asumsi bahwa nilai MSA yang berada di bawah $<0.5$ harus dieliminasi.

Ketiga, Hasil uji reliabilitas instrumen sikap keberagamaan mahasiswa Fakutas Tarbiyah dan Keguruan IAIN Raden Intan Lampung dengan menggunakan skala Thurstone terdiri dari 35 butir menunjukkan nilai koefisen alpha cronbach sebesar 0.852 dengan asusmi bahwa tingkat reliabilitas instrumen in tergolong tinggi. 


\section{Daftar Pustaka}

Arifin, Bambang Syamsul, 2008. Psikologi Agama, Bandung: Pustaka Setia,.

Abdullah, Amin. 2004. Studi Agama Normativitas atau Historisitas (Yogyakarta: Pustaka Pelajar.

Azwar, Saifuddin. 2011. Sikap Manusia Teori dan Pengukurannya. Yogyakarta: Pustaka Pelajar.

Bahtiar, Amsal, 2007. Filsafat Agama, Jakarta: Raja Grafindo,

Carr, David, dan John Haldane, 2003. Spirituality, Philosophy and Education, New York: Routledge Falmer

Djaali, 2008. Pengukuran dalam Bidang Pendidikan, Jakarta: Grasindo.

Durkheim, Emile 2011.The Elementary Forms of The Religious Life, terjemahan M. Syukri Yogyakarta: Ircisod.

Ghazali, Adeng Muchtar. 2011. Antropolgi Agama. Bandung: Alfabeta,

Harrington Donna, 2009. Confirmatory Factor Analysis, New York: Oxford University Press.

Hefner, Robert W, 2009. Making Modern Muslim The Politics Of Islamic Education In Southeast Asia, Honolulu: University of Hawaii.

Kerlinger, Fred N, 2004. Asas-Asas Penelitian Behavioral, terjemahan Landung N. Simatupang, Jogjakarta: UGM Press.

Kasmahidayat, Yuliawan, 2010. Agama dalam Transformasi Budaya Nusantara, Bandung: Bintang Warliartika,

Mangunjiwa, Y.B, 1991. Menumbuhkan Sikap Religius Anak-anak, Jakarta: Gramedia,

Mastuhu, 2006. Metodolgi Penelitian Agama, Jakarta: Rajawali Pers.

Mutahhari, Murtadha, 2008. Manusia dan Alam Semesta. Jakarta: Lentera.

Nasr, Sayyed Hossein. 2004. Intelegensi Spiritualitas Agama-Agama, terjemahan Suharsono. Jakarta: Inisiasi Press. 
Purwanto, 2010. Metodologi Penelitian Kuantitatif. Yogyakarta: Pustaka Pelajar,

Ramayulis , 2011. Psikologi Agama, Jakarta: Kalam Mulia

Raykov, Tenko, 2006. A First Course ini Structural Equation Modeling, London: Lawrence Erlbaum Assosiates Publisher.

Richey Rita C. dan James D. Klein, 2007. Design and Development Research: Methodes, Strategies, and Issues, New Jersey: Lawrence Erlbaum.

Semiawan R. Conny, 2008. Catatan Kecil tentang Penelitian dan Pengembangan Ilmu Pengetahuan, Jakarta: Kencana Prenada Media Group.

Santoso, Singgih, 2014. Statistik Multivariat Konsep dan Aplikasi dengan SPSS, Jakarta: Gramedia,

Suryabrata, Sumadi, 2005. Alat Ukur Psikologis, Yogyakarta: Andi.

Sutrisno, Muji, 2005. Teks-Teks Kunci Estetika, Filsafat, Seni, Jogjakarta: Galang Press.

Warwanto, Heribertus Joko dkk, 2009. Pendidikan Sikap Keberagamaan, Yogyakarta: Kanisius, 